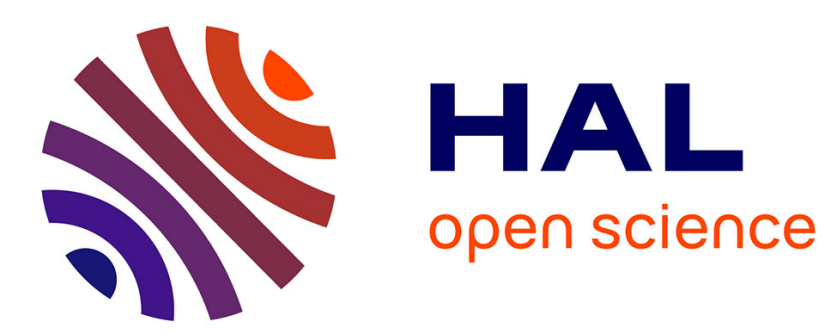

\title{
2019: Homicide Big Comeback in France
}

Alain Bauer, Christophe Soullez

\section{To cite this version:}

Alain Bauer, Christophe Soullez. 2019: Homicide Big Comeback in France. International journal on criminology , 2020, 7 (2), pp.1-5. 10.18278/ijc.7.2.2 . hal-03218187

\section{HAL Id: hal-03218187 \\ https://hal.science/hal-03218187}

Submitted on 5 May 2021

HAL is a multi-disciplinary open access archive for the deposit and dissemination of scientific research documents, whether they are published or not. The documents may come from teaching and research institutions in France or abroad, or from public or private research centers.
L'archive ouverte pluridisciplinaire HAL, est destinée au dépôt et à la diffusion de documents scientifiques de niveau recherche, publiés ou non, émanant des établissements d'enseignement et de recherche français ou étrangers, des laboratoires publics ou privés. 


\title{
2019: Homicide Big Comeback in France
}

\author{
Alain Bauer \\ Professor of Criminology at the Conservatoire National des Arts et Métiers, New York and \\ Shanghai
}

Christophe Soullez

Head of the National Observatory of Delinquency and Penal Responses

$$
\text { ABSTRACT }
$$

The annual number of homicides is one of the main statistics for criminologically characterizing a territory, be it a city, a region or a country. It can be used to conduct situational analyses of the recent past or, if looking at a longer time period or comparing jurisdictions, it can be compared to the number of people living in a jurisdiction. This gives the reference indicator for the level of violence, the homicide rate. The balance sheet published at the beginning of 2020 by the Ministry of the Interior nevertheless confirms this deterioration with an increase in the number of homicide victims (including assault and battery followed by death) of $12.4 \%$ in one year, thus beating the tragic record of 1983 $(3,562$ acts against 3,183) and becoming the worst result since 1972 in gross numbers and the third in relation to the population with a rate of 5.32 per 100,000 inhabitants against 5.68 in 1983 and 5.42 in 1986. In any case, a profound return of physical violence seems to be taking place, particularly in the West. It is being ignored, whether voluntarily or involuntarily, or underestimated. Its causes are undoubtedly multiple, but the increase in the number of victims cannot be underestimated for much longer.

Keywords: France, Homicide, Violence, Statistics

The annual number of homicides is one of the main statistics for criminologically characterizing a territory, be it a city, a region or a country. It can be used to conduct situational analyses of the recent past or, if looking at a longer time period, or comparing jurisdictions, it can be compared to the number of people living in a jurisdiction. This gives the reference indicator for the level of violence, the homicide rate. It is generally expressed per 100,000 inhabitants.

The annual number of homicides is usually part of the statistics available promptly after the end of each year. Indeed, checks carried out in the course of the year make it possible to have almost exhaustive information on the victims of 
homicides from the previous year at the beginning of January. In some territories, the annual homicide toll is thus commented on very early on.

This is the case, for example, in the major cities of the United States, where the 2019 homicide figures were the subject of press articles, sometimes as early as December 31st. We were thus able to find out about the trends observed, whether there were declines in cities such as Chicago, New York (except for homicides), or Los Angeles, or peaks in other cities such as Baltimore and Philadelphia.

But, while we are rightly moved by the increase of mass murders and the homicide rate in the United States (about 5 per 100,000), and even more so in countries such as Mexico (about 20 per 100,000), or Brazil (about 30 per 100,000), an inconspicuous but increasingly accentuated trend is affecting France and is raising its rate from the low point reached in 2014 (close to 1 per 100,000).

The most shocking part of this trend, the "feminicides" (formerly uxoricides), is rightly shocking. But this situation seems to hide an even more disturbing one: that the overall numbers of homicides and attempts (failed homicides) has increased.

A detailed analysis of the police homicide count tool (Etat 4001) since 1972 shows identified cycles and a clear deterioration in an accelerating phase.

In order to get closer to the truth (the homicides taken into account by the police are not the same as those recorded by other services such as Health or Justice), we considered that the error variable was stable over the period, as the Ministry of the Interior's measurement tool had not been structurally modified (it should be noted, however, that attempted homicides are only clearly identified from 1987 onwards).

Moreover, since 2015, following a report by the National Observatory of Delinquency and Penal Responses (ONDRP) on the double counting of certain homicides, the Ministerial Statistical Service of Internal Security (SSMSI) has been making corrections that make the tool more unstable than usual, even though this is often for a technically justified cause.

Thus, from 1994 to 2014, the National Observatory of Delinquency and Penal Responses (ONDRP) had described a phenomenon of continuous decline in the 
homicide rate, the main component of a Western movement called crime drop in Anglo-Saxon countries.

In an article published in December 2015, it was reported that between 1994 and 2014 , the homicide rate had fallen by almost $60 \%$ in metropolitan France.

In November 2018, in the newspaper Libération, Cédric Mathiot, a journalist who pioneered fact checking in France, looked into the subject, following a question asked via the Checknews website by Cyril Rizk, former head of the ONDRP. In the article entitled "Homicides: Beauvau is afraid of his number" we learned that if we confine ourselves to "only homicides (excluding intentional assault and battery followed by death, which the interior ministry counts) in metropolitan France" their 12-month level was "clearly on the rise, breaking the trend of decline and then stagnation observed for nearly 15 years." Cyril Rizk then offered an explanation: the attacks "have changed the nature of homicidal violence committed in France. They have also changed the way the issue of violence is addressed in public debate. The fight against terrorism has become the number one security issue, relegating everyday security problems to the background. Monthly figures from the police and gendarmerie now suggest that something may have slipped through the cracks.

In other words, no one would have seen anything. The interior ministry had been contacted several times but had not replied, first questioning the figures provided and then saying that it wanted to "get to the bottom of this" before commenting on them.

However, according to provisional official data published on 7 January 2020, there has been an 8.5\% increase over one year in metropolitan France, i.e. 76 more victims between 2018 (894) and 2019 (970). However, the provisional data should still be treated with caution. The provisional figure for 2017 had been revised from 896 to 825 , while the 2018 figure had been revised from 894 to 845 . The final fig2019: Homicide Big Comeback in France 5 ures for 2015 and 2016, 872 and 892 victims respectively, have the particularity of including the mass crimes resulting from the attacks of 13 November 2015 and 14 July 2016.

We are therefore faced with the strong possibility that the final figure for homicides in 2019 could exceed 900, which would make it a deadlier year than the years when the Bataclan attacks or the killing of the Promenade des Anglais in Nice occured, albeit without any major attack. 
But there is also a clear trend towards homicide (homicides, attempts and intentional assault and battery resulting in death) which reverses a long process of decline in ultimate violence. Indeed, if all homicides and attempted homicides are taken together, the summary table shows a situation that slowly deteriorated between 1972 and 1983 (from 2,093 to 3,183 incidents, i.e. an overall increase of 52 per cent).

There are considerable differences in the settlement of accounts: 69 in 1972, 105 in 1973, 85 in 1974, then after a certain stability, 184 in 1983). The same is true for children, with a high level in 1972 (140), a rapid decrease (44 in 1978) and a sharp increase in 1982 (109). From 1987 onwards, erratic movements can be observed (sharp fall in 1987: 2,496 victims including 59 children) followed by a sharp rise in 1988 (2,835 including 101 children). The level of homicide will remain high with a good year in 1994 for minors (only 13 victims).

It was not until 2009 that the threshold of 2,000 victims was broken at the bottom (1,767 incidents). This level will rise again in 2011 and accelerate sharply in 2015 (2,805 victims following the attacks of 13 November), and will continue until 2018 with 3,168 recorded incidents (the highest level in 35 years and the second worst record in modern homicide statistics), including 84 settlements of accounts (the highest level in 10 years) and 67 minor victims.

The balance sheet published at the beginning of 2020 by the statistical service of the Ministry of the Interior nevertheless confirms this deterioration with an increase in the number of homicide victims (including assault and battery followed by death) of $12.4 \%$ in one year, thus beating the tragic record of 1983 (3,562 acts against 3,183 ) and becoming the worst result since 1972 in gross numbers and the third in relation to the population with a rate of 5.32 per 100,000 inhabitants against 5.68 in 1983 and 5.42 in 1986. The data will have to be adjusted in the coming weeks, but the characteristics of the phenomenon will also have to be clarified: methods of operation (firearms, knives or other weapons), profiles of victims and perpetrators, and the places where crimes are committed.

In any case, a profound return of physical violence seems to be taking place, particularly in the West. It is being ignored, whether voluntarily or involuntarily, or underestimated. Its causes are undoubtedly multiple, but the increase in the number of victims cannot be underestimated for much longer. 
For, behind this violence of everyday life, masked by attacks or mass murder, there is a global social process of questioning a founding achievement of what makes civilization what it is: the right to live. For women, minors ... and men, the violence that is coming back seems to be overwhelming the whole society, and not only in the streets ... 